\title{
Stem Cell Therapy for Liver Diseases
}

\author{
Aliya Siddiqui ${ }^{1 *}$, Jeevani $\mathrm{T}^{2}$, Naga Anusha $\mathrm{P}^{3}$ and Hima Bindu $\mathrm{A}^{4}$ \\ ${ }^{1}$ Department of Biotechnology, Chaitanya P.G. College, Kakatiya University, India \\ ${ }^{2}$ Department of Biotechnology, Acharya Nagarjuna University, Guntur, India \\ ${ }^{3}$ Department of Biotechnology, Sri Y.N. College, Andhra University, India \\ ${ }^{4}$ Department of Biotechnology, Andhra Vidyalaya P.G College, Osmania University, India
}

\begin{abstract}
Liver failure and liver diseases are major health problems worldwide leading to high mortality and also one of the high healthcare costs. Millions of patients die due to liver pathologies and liver diseases every year throughout the world. Use of stem cells to cure liver diseases has been proved beneficial in most of the conditions. Scientific literature reveals the role of stem cells in treatment and cure of various diseases like Liver Cirrhosis, End Stage liver Failure, genetic liver disease and also the Liver cancer. The stem cells possess the ability to renew and multiply by them or stem cells possess special characteristics of regenerating themselves. Because of their ability stem cells can differentiate into any tissue type, they have huge potential in various disease therapies and traumatic injuries. Stem cell therapy can be considered as an alternative to liver transplantation, as it has the immense potential in management of liver failure. Stem cell therapy can be mediated by either embryonic, induced pluripotent or adult stem cells or by promotion of endogenous regenerative processes with bone marrow-derived stem cells. Ethical issues and concerns make reduce the use of embryonic stem cells as a source to cure liver diseases when compared to adult stem cells.
\end{abstract}

Keywords: Liver Diseases; Liver Cirrhosis; Liver cancer; Transplantation; Stem cell Therapies; Bone marrow stem cells; Adult stem cells; Embryonic stem cells; Ethical issues

\section{Introduction}

Liver failure is a growing health problem and one of the main causes of death worldwide. Hundreds of millions of patients worldwide are affected with liver pathologies [1]. Discovery of stem cells reveals that they are capable of differentiating into specialized cell types, including the hepatocytes, by utilizing these hepatocytes damaged liver can be regenerated [2]. Liver failure and hepatocellular damage may also leads to death of many patients who are waiting for liver transplantation [3]. Scientists have paid their attention to the field of stem cells, which has helped to understand the pathogenesis of liver disease, and thereby expanding the drug discovery processes, which could be used as an alternative therapy [4]. Liver like cells derived from bone marrow and embryonic stem cells, results in better understanding of the biochemical compounds that are essential in liver development [5]. The most common causes of hepatopathy are alcoholism, chronic hepatitis $\mathrm{C}$ and $\mathrm{B}$, nonalcoholic fatty liver disease, autoimmune, and drug-induced hepatic disorders [6]. Hepatitis C virus (HCV) is the most common and is a leading cause of liver disease in America $[7,8]$. Accumulation of Cadmium in higher quantity may also leads to liver damage [9]. Many of these diseased conditions can be prevented or treated either by using precautions and drugs but if they are not treated at proper time, they can lead to liver injury, liver fibrosis and ultimately cirrhosis, portal hypertension, liver failure, and, in some cases, it may also leads to cancer $[10,11]$. There are currently more than 5 million people in the United States suffering from end-stage liver pathologies, whose curative therapy is liver transplantation. More than 5,000 liver transplants are performed in the United States each year (including more than 500 in children). About 20,000 people are waiting for Liver Transplantation, but only 7,000 transplants are performed annually and as many as 1,500 patients die yearly while on the waiting list. A significant cause of liver cancer related mortality, with over 140,000 new cases and 50,000 deaths in the United States each year [12]. Patients with advanced liver disease can be treated with stem cells taken from their own skin or blood in a breakthrough that could save thousands of lives. Disturbance in normal function of liver which leads to illness is known as liver disease. The liver is responsible for many critical functions in the body and loss of those functions may leads to damage of the body. Liver is considered as the main metabolizing organ in the body as various kinds of metabolic reactions takes place inside it [13-16], Liver disease is also referred to as hepatic disease [17]. The liver is the only organ in the body that can easily replace damaged cells, but if enough cells are lost, the liver may not be able to meet the needs of the body.

\section{Role of Stem cells in Liver Repair}

Stem cells are considered as Master cells of the body [18]. Stem cells are biological cells found in all multicellular organisms, that can divide (through mitotic cell division) and differentiate into diverse range of specialized cell types and can self-renew to produce more stem cells [19]. There are mainly two types of stem cells: embryonic stem cells, which are isolated from the inner cell mass of blastocysts, and adult stem cells, which are found in various tissues [20]. Stem cells can be taken from a variety of sources, including umbilical cord blood, bone marrow etc. Stem cells possess two special properties like:

Self-renewal: The ability of stem cells to go through numerous cycles of cell division while maintaining the undifferentiated state [21].

*Corresponding author: Aliya Siddiqui, Department of Biotechnology, Chaitanya P.G. College, Kakatiya University, Warangal, India, E-mail: aliya.siddiqui53@ gmail.com

Received October 14, 2011; Accepted November 12, 2011; Published November 14,2011

Citation: Siddiqui A, Jeevani T, Naga Anusha P, Hima Bindu A (2011) Stem Cell Therapy for Liver Diseases. J Stem Cell Res Ther 1:111. doi:10.4172/21577633.1000111

Copyright: $\odot 2011$ Siddiqui $\mathrm{A}$, et al. This is an open-access article distributed under the terms of the Creative Commons Attribution License, which permits unrestricted use, distribution, and reproduction in any medium, provided the original author and source are credited. 
Potency: The capacity of stem cells to differentiate into specialized cell types.

Various Definitions for the liver stem cells include:

$>$ Cells responsible for normal tissue turnover.

$>$ Cells that give rise to regeneration after partial hepatectomy.

$>$ Cells responsible for progenitor-dependent regeneration.

$>$ Cells that produce hepatocyte and bile duct epithelial phenotypes in vitro.

> Transplantable liver-repopulating cells. This review will consider liver stem cells in the context of each definition.

Embryonic stem cells (ESCs) and adult somatic cells can be differentiated into hepatocyte-like cells with potential use in drug testing, bio-artificial livers and transplantation [22].

\section{Diseases treated using Stem cells}

Different Liver diseases can be treated using stem cells like Liver Cirrhosis, Genetic liver diseases and liver necrosis etc [23]. In response to liver injury or loss of liver mass, proliferation of mature liver cells is the first-line defense to restore liver homeostasis [24].

Liver Cirrhosis: Cirrhosis is a condition in which the liver slowly deteriorates and malfunctions due to chronic injury. Scar tissue replaces healthy liver tissue and a condition where partial blockage of flow of blood through the liver is seen. Liver Transplantation was approved for treatment of cirrhosis [25]. Scarring also impairs the liver's ability to:

\section{$>$ Control infections}

$>$ Remove bacteria and toxins from the blood

$>$ Process nutrients, hormones, and drugs

$>$ Make proteins that regulate blood clotting

$>$ Produce bile to help absorb fats including cholesterol and fatsoluble vitamins

Cirrhosis is the twelfth leading cause of death by disease, accounting for 27,000 deaths each year [26]. The condition affects men slightly more often than women. In the United States, heavy alcohol consumption and chronic hepatitis $\mathrm{C}$ have been the most common causes of cirrhosis [27]. Cirrhosis is neither caused by trauma to the liver nor by any other acute, or short-term, causes of damage to liver whereas it usually requires years of chronic injury to liver to cause cirrhosis [28]. Heavy Alcohol consumption may also leads to liver failure and other liver diseases $[29,30]$.

\section{Alcohol related liver diseases}

$>$ Chronic hepatitis C

$>$ Chronic hepatitis B and D

$>$ Nonalcoholic fatty liver disease (NAFLD)

$>$ Autoimmune hepatitis

$>$ Diseases that damage or destroy bile ducts

$>$ Inherited diseases

Drugs, toxins, and infections

Human induced pluripotent stem (iPSC) cells hold great promise for advancements in cell therapy [31]. Researchers have found a way to produce millions of the cells that can be injected into the organ to help regenerate it. The technique involves extraction of cells from skin and blood again converting them back to their original stem cell state and then into liver cells. These cells were then injected into a liver with cirrhosis [32]. The stem cells taken from skin or blood are known as "induced Pluripotent stem cells" (iPSC) [33]. The advantage of using induced-pluripotent stem cells (iPSC) is that they are cheap and can be multiplied easily in the laboratory. "iPSC" derived liver cells not only can be generated in large amounts, but also can be tailored to each patient, preventing immune-rejection problems which are associated with liver transplants from unmatched donors or embryonic stem cells. The technique involves taking blood from patients, then removal of stem cells that circulates in the bloodstream and multiplying them in a laboratory. They are infused back into the liver via a main artery where they continue to multiply as liver cells.

Genetic liver disease can be cured by skin stem cells: Scientists believe to mend or repair the defective genes in stem cells, which create various types of tissues in the body, could acclaim a new era of therapies for a wide range of genetic disorders [34]. By producing a certain protein, the researchers targeted a gene that protects against inflammation in the liver. The protein gets trapped in the liver, in patients with a gene mutation, and leads to liver cirrhosis and lung emphysema. Making use of "molecular scissors" the scientists were able to cut away the mutated section of DNA from a stem cell and replace it with a corrected version [35]. The stem cells went on to generate liver cells, which contained normal protein levels, indicating that the previously faulty gene was now working normally.

\section{Liver Transplantation}

Liver transplantation or hepatic transplantation is the replacement of a diseased liver with a healthy liver allograft [36]. The most commonly used technique is orthotopic transplantation, in which the native liver is removed and replaced by the donor organ in the same anatomic location as the original liver [37]. The transplant operation can be conceptualized as consisting of the hepatectomy (liver removal) phase, the anhepatic (no liver) phase, and the post implantation phase [38].

End Stage Liver Failure: Though the liver can regenerate in the body, end-stage liver failure caused by diseases like cirrhosis and cancers eventually destroys the liver's regenerative capacity [39]. Patients with End stage liver failure cannot be treated with any kind of medications and preventions; the only option for those patients is to receive a liver organ from a donor or liver cell transplant $[40,41]$.

Liver Cancer: Cancer occurs in different cell types [42,43,44]. Cancer is the state of cells, where unregulated proliferation takes place $[45,46]$. Liver cancer is one of the most common cancers and has been especially hard to treat [47]. Primary liver cancer including hepatocellular carcinoma (HCC) and cholangiocarcinoma is the sixth most common cancer worldwide $[48,49,50]$. Generally cancer cells develop from normal cells due to damage of DNA [51,52]. Hepatocellular carcinoma (HCC) is the sixth most common cancer in the world, with most HCC occurring in the setting of cirrhosis and infection of the hepatitis $\mathrm{B}$ or $\mathrm{C}$ viruses [53,54]. Patients with liver tumors are also considered as one of the major concerns of international healthcare [55]. Though Scientists have been made some recent advances using stem cells, but right now the main treatment for liver cancers is to cut the cancerous parts out of the liver. This type of treatment works well because liver is a special 
organ which can actually regrow by it. As a result, surgeons can remove most of the liver and the rest will grow back and work normally. Most liver cancers spread too fast and through too much of a patient's liver [56]. The cancer can no longer be removed by surgery because there wouldn't be enough liver left behind. In a study, Researchers compared the results of portal vein embolization (PVE), a technique which is currently used to help regenerate liver tissue, to a combination of PVE and an injection of bone marrow stem cells into the liver [57]. PVE blocks blood flow to the diseased portion of the liver and diverts blood to the organ's healthy tissue, promoting liver growth [58]. Stem cells extracted from Bone Marrow of a patient's hip bone and injected into the liver also help the liver to regenerate [59]. Some of the cancer treatments may also cause side effects [60].

\section{Stem cell therapies for liver disease}

\section{Stem cells provide new ways to treat chronic liver disease:}

Various Therapies and technologies were used to treat liver and also other diseases like neural disorders $[61,62,63,64,65,66]$. Researchers are working more precisely, in order to understand how the liver stem cells could be used to treat patients. To produce new hepatocytes in the laboratory [67] embryonic stem cells or induced pluripotent stem cells might be used for those patients whose liver has lost the capacity to regenerate. Stem cells are used for transplantation purpose [68]. Bone Marrow transplantation is very useful to treat disorders [69].

Bone marrow cells used to treat chronic liver disease: Another route to new treatments might be to use cells made from a patient's own bone marrow to help repair damaged liver tissue [70]. Bone marrow derived Mesenchymal stem cells have the capacity to differentiate into several cell types [71]. These cells can be grown in the laboratory:

$>$ Bone marrow cells are harvested from the thigh bone of a mouse.

$>$ The bone marrow contains a mixture of cells. The cells are grown under carefully controlled conditions.

$>$ The cells are then put into the diseased liver of the mouse.

The cells have a beneficial role in regenerating liver tissue and reversing scarring in the liver. When scarring is reduced, the liver is able to work better [72].

Embryonic stem cells and fetal liver stem cells used to treat liver disease: Embryonic Stem Cells and their derivatives might constitute an easily available source to obtain a large number of transplantable cells for regenerative treatments. In contrast to adult liver, Embryonic Stem Cells and fetal liver Stem Cells are thought to be highly proliferative, less immunogenic and more resistant to cryopreservation [73]. Fetal liver Stem cells, also named "hepatoblasts", appear when the hepatic endoderm has been specified and the liver bud is growing. Hepatoblasts are bipotent, being able to give rise to both hepatocytes and bile duct cells [74]. Embryonic stem cells and fetal liver stem cells can give rise to new cells and thus possess the capacity to regenerate new liver cells. But the Embryonic stem cells have the Ethical issues and concerns like Embryo destruction and fetal injury to extract the embryonic stem cells as a source to generate new cells in the laboratory [75].

Induced pluripotent stem cells used to treat liver disease: Induced pluripotent stem cells (iPSCs) are embryonic like Stem Cells derived from somatic cells [76]. Theoretically, iPSCs could be obtained from the same patient and used for tissue replacement or gene therapy. Human induced pluripotent stem cells (iPSCs) are a potential source of hepatocytes for liver transplantation to treat end-stage liver disease [77].

Placental and Umbilical cord blood stem cells used to treat liver disease: Placental cells and Umbilical cord blood cells have higher proliferation and differentiation potential than Adipose derived Stem Cells [78]. Several studies indicated that umbilical cord and umbilical cord blood, placenta and amniotic fluid are an easily accessible source of pluripotent Stem Cells, which may be readily available for transplantation [79]. These cells can be extensively expanded without loss of potency and have a broad differentiation potential, since they can generate progenies of all three germ layers. These pluripotent stem cells are capable of liver repopulation in vivo, upon transplantation in animal models [80].

Adult stem cells used to treat liver disease: Adult stem cell treatments have been used for many years to successfully treat leukemia and related bone/blood cancers utilizing bone marrow transplants. Adult stem cells are used to treat many other diseases [81]. The adult stem cells undergo rapid proliferation when it needs to regenerate the specialized tissues [82]. As the production of adult stem cells does not require any kind of embryonic destructions their use in research and therapy is not considered as controversial when compared to embryonic stem cells [83]. In common with embryonic stem cells, adult stem cells have the ability to differentiate into more than one cell type, but they are often restricted to certain types or "lineages". Adult stem cells are more capable of transdifferentiation than other cells. Liver regeneration is mainly an endogenous process, driven by hepatocytes and resident hepatic stem/progenitor cells [84]. It has been observed that certain populations of extra hepatic Adult Stem Cells can migrate into the liver and contribute to its repopulation and turnover [85]. A particularly high degree of plasticity has been shown by bone marrow stem cells (BMSCs), which can give rise to a wide range of phenotypes, including hepatocyte like cells.

\section{Conclusion}

The study of Endogenous liver Stem cells and investigation of stem cell therapy approaches for liver diseases are rapidly evolving fields that hold promise for both increasing and understanding of the mechanisms of liver development and liver repair and providing potential new therapeutic avenues for the treatment of liver diseases. A diseased liver can be supported or substituted with new tissues generated by liver tissue engineering. Stem cell transplantation is a complex process that requires the care of experts. The controversies associated with the ethical, legal and social issues of certain areas of stem cells research and stem cells potential clinical applications must be carefully examined to ensure that science remains as the vehicle for hope and not harm. After all advancing treatment and care for patients to save liver is and must be our ultimate goal.

\section{References}

1. Sapisochin G, Charco R (2011) Salvage Liver Transplantation for HCC: An Old Story without Consensus? J Transplant Technol Res 1:106e.

2. Navarro-Alvarez N, Soto-Gutierrez A, Kobayashi N (2009) Stem cell research and therapy for liver disease. Curr Stem Cell Res Ther 4: 141-146.

3. Hassan GM, Mazher KHM (2011) Genotoxicity and Histopathological Studies on the Liver, Kidney and Lymphocytes of Male Rats Fed on Diet Containing Waste Fat Released from Chicken During Grilling Process. J Cytol Histol 2: 111.

4. Hill EJ, Sharma RA (2011) Multi-modality Therapy of Hepatic Metastases from Colorectal Carcinoma: Optimal Combination of Systemic Chemotherapy with Radio-embolization. J Nucl Med Radiat Ther 2: 108. 
Citation: Siddiqui A, Jeevani T, Naga Anusha P, Hima Bindu A (2011) Stem Cell Therapy for Liver Diseases. J Stem Cell Res Ther 1:111. doi:10.4172/2157-7633.1000111

5. Souza BS, Nogueira RC, de Oliveira SA, de Freitas LA, Lyra LG, et al (2009) Current status of stem cell therapy for liver diseases. Cell Transplant 18: 12611279.

6. Yang X, Li Z, Su Z, Davis K, Chen T, et al. (2011) Urinary Micrornas as Noninvasive Biomarkers for Acetaminophen-Induced Liver Injury. J Postgenom Drug Biomark Develop 1: 101

7. Ramsey SE, Engler PA, Stein MD, Brown RA, Cioe P et al. (2011) Effect of CBT on Depressive Symptoms in Methadone Maintenance Patients Undergoing Treatment for Hepatitis C. J Addict Res Ther 2: 109.

8. Mata RC, Mira JA, Rivero A, López-Cortés LF, Torres-Tortosa M, et al. (2010) Nevirapine-based Antiretroviral Therapy is Associated with Lower Plasma Hepatitis C Virus Viral Load among HIV/Hepatitis C Virus-Coinfected Patients. J AIDS Clinic Res 1: 110

9. Mahran AA, Husam Eldien HO, Abd El-Mawla AMA, Attia AM (2011) Protective Effect of Zinc $(Z n)$ on the Histology and Histochemistry of Liver and Kidney of Albino Rat Treated with Cadmium. J Cytol Histol 2: 123.

10. Kivity S, Ben-Haim M, Guranda L, Olchovsky D (2011) Shocking Liver. Rheumatology 1: 103.

11. Mira JA, López-Cortés LF, Vispo E, Tural C, Laguno M, et al. (2010) Concomitan Nevirapine Therapy is Associated with Higher Efficacy of Pegylated Interferon Plus Ribavirin among HIV/Hepatitis C Virus-Coinfected Patients. J AIDS Clinic Res 1: 112.

12. Meyer JE, Cohen SJ (2011) Beyond First-Line Therapy: Combining Chemotherapy and Radioembolization for Hepatic Colorectal Metastases. J Nucl Med Radiat Ther 2: 103.

13. Grundmann O (2010) The Gut Microbiome and Pre-systemic Metabolism: Current State and Evolving Research. J Drug Metabol Toxicol 1: 104.

14. Dang Q, Reddy KR, Kasibthatla SR, Jiang T, Taplin F, et al. (2010) Discovery of Phosphonic Acid-Containing Desaminobenzimidazoles as Fructose 1,6-Bisphosphatase Inhibitors that are Suitable for Oral Delivery via Prodrugs. J Diabetes Metab 1: 105.

15. Douroumis D (2011) Mesoporous silica Nanoparticles as Drug Delivery System. J Nanomedic Nanotechnol 2: 102e.

16. EL-Shenawy NS, El-Ahmary B, Al-Eisa RA (2011) Mitigating Effect of Ginge against Oxidative Stress Induced by Atrazine Herbicides in Mice Liver and Kidney. J Biofertil Biopestici 2: 107.

17. Ying J, Quanjun W, Jinglan W, Songfeng W, Gang C, et al. (2008) Profiling of Phosphorylated Proteins in Human Fetal Liver. J Proteomics Bioinform 1: 437-457

18. Seo GS (2011) Stem cell properties of therapeutic potential. Korean $J$ Gastroenterol 58: 125-132.

19. Shrihari TG (2011) Cancer Stem Cells - Therapeutic Boon! J Cancer Sci The 3: $197-200$.

20. Quante M, Wang TC (2009) Stem cells in gastroenterology and hepatology. Nat Rev Gastroenterol Hepatol 6: 724-737.

21. Sai YRKM, Dattatreya A, Anand SY, Mahalakshmi D (2011) Biomarkers and their Role in Premonition, Interpretation and Treatment of Cancer. J Cancer Sci Ther R1: 002

22. Kung JW, Forbes SJ (2009) Stem cells and liver repair. Curr Opin Biotechnol 20 568-74.

23. Polaniak R, Bułdak RJ, Jacheć W, Helewski K, Wojnicz R, et al. (2011) Long-term Exposure to Acetaminophen is a Crucial for Activity of Selected Antioxidative Enzymes and Level of Lipid Peroxidation Process in Rat Liver. J Bioequiv Availab 3: 182-186.

24. Greenbaum LE, Wells RG (2011) The role of stem cells in liver repair and fibrosis. Int J Biochem Cell Biol. 43: 222-229.

25. Mukherjee S (2009) Antiviral Therapy for Hepatitis B in Preand Post-liver Transplant Patients. J Antivir Antiretrovir 1: 017-027.

26. Miniño AM, Heron MP, Murphy SL, Kochanek KD (2007) National Vital Statistics Reports.

27. Castellanos MI, Seijas OR, González D, Ronquillo M, del Rosario Abreu M, et al. (2011) Immune Alterations in Liver Cirrhosis: Its Relationship with Etiology, Child Pugh Stage and Malnutrition. J Nutrition Disorder Ther 1: 101.
28. Nellithady GS, Anila K, Kumar KK, Kaveri H (2010) Lack of Association of Chronic Liver Disease in Patients with Oral Lichen Lanus. J Carcinogene Mutagene 1: 113.

29. Kolla BP, Bostwick JM (2011) Insomnia: The Neglected Component of Alcohol Recovery. J Addict Res Ther 2: 0e2

30. Demarie D, Marletta G, De Vivo E, Rivela E, Bignamini E (2011) Long QT Syndrome (LQTS) in Opiate, Cocaine and Alcohol Addiction, with HIV+ / HCV+ Co-Infection in Antiretroviral Therapy (HAART). J Addict Res Ther 2: 114.

31. Rashid ST, Corbineau S, Hannan N, Marciniak SJ, Miranda E, et al. (2010) Modeling inherited metabolic disorders of the liver using human induced pluripotent stem cells. J Clin Invest 120: 3127-3136.

32. Ferber $S$ (2000) Can we create new organs from our own tissues? Isr Med Assoc J 2: 32-36.

33. Chun YS, Chaudhari $P$, Jang $Y Y$ (2010) Applications of patient-specific induced pluripotent stem cells; focused on disease modeling, drug screening and therapeutic potentials for liver disease. Int J Biol Sci 6: 796-805

34. Wu G, Liu N, Rittelmeyer I, Sharma AD, Sgodda M, et al. (2011) Generation of healthy mice from gene-corrected disease-specific induced pluripotent stem cells. PLoS Biol 9: e1001099.

35. Durai S, Mani M, Kandavelou K, Wu J, Porteus MH, et al. (2005) Zinc finge nucleases: custom-designed molecular scissors for genome engineering of plant and mammalian cells. Nucleic Acids Res 33: 5978-90.

36. Harring TR, Nguyen NT, Goss JA, O'Mahony CA (2011) Human T-Cell Lymphoma Virus-Positive Allograft Used For Effective Orthotopic Live Transplantation: A Case Report and Review of the Literature. J Transplant Technol Res 1: 102.

37. Vitin AA, Martay K, Vater Y, Dembo G, Maziarz M (2010) Effects of Vasoactive Agents on Blood Loss and Transfusion Requirements During Pre-Reperfusion Stages of the Orthotopic Liver Transplantation. J Anesthe Clinic Res 1: 104

38. Lins Kusterer LEF (2011) Oral Diseases and Liver Pre and Post-Transplantation Disorders. J Transplant Technol Res S1: 001.

39. Piscaglia AC, Campanale M, Gasbarrini A, Gasbarrini G (2010) Stem cellbased therapies for liver diseases: state of the art and new perspectives. Stem Cells Int 259461

40. Zhao Y, Haney MJ, Mahajan V, Reiner BC, Dunaevsky A, et al. (2011) Active Targeted Macrophage-mediated Delivery of Catalase to Affected Brain Regions in Models of Parkinson's Disease. J Nanomedic Nanotechnol S4: 003.

41. Sinnathamby G, Zerfass J, Hafner J, Block P, Nickens Z, et al. (2011) EDDR1 is a Potential Immunotherapeutic Antigen in Ovarian, Breast, and Prostate Cancer. J Clin Cell Immunol 2: 106.

42. Skogseth H, Tvedt KE, Halgunset J (2011) Carcinoma Metastasis - An Approach to Models. J Carcinogene Mutagene 2: 119.

43. Naga Deepthi CH, VVL Pavan Kumar A, Rameshbabu, Indirapriyadarshin U (2011) Role of Tumor Suppressor Protein p53 in Apoptosis and Cance Therapy. J Cancer Sci Ther R1: 001.

44. Ferreira AK, Meneguelo R, Neto SC, Chierice GO, Maria DA (2011) Synthetic Phosphoethanolamine Induces Apoptosis Through Caspase-3 Pathway by Decreasing Expression of Bax/Bad Protein and Changes Cell Cycle in Melanoma. J Cancer Sci Ther 3: 053-059.

45. Castellanos MI, Seijas OR, González D, Ronquillo M, del Rosario Abreu M, e al. (2011) Immune Alterations in Liver Cirrhosis: Its Relationship with Etiology, Child Pugh Stage and Malnutrition. J Nutrition Disorder Ther 1:101

46. Nguyen KT (2011) Targeted Nanoparticles for Cancer Therapy: Promises and Challenges. J Nanomedic Nanotechnol 2: $103 \mathrm{e}$.

47. Mi Z, Guo H, Markovic J, Kuo PC (2009) Characterization of Osteopontin Binding Kinetics In MDA-MB231 Breast and SK-Hep-1 Liver Cancer Cells. J Cancer Sci Ther 1: 047-051.

48. Burrill J, Hafeli U, Liu DM (2011) Advances in Radioembolization - Embolics and Isotopes. J Nucl Med Radiat Ther 2: 107.

49. Ettorre GM, Vennarecci G, Santoro R, Miglioresi L, Lepiane P, et al. (2011) Experiences in Hepatic Surgery and Transplantation after Radioembolization J Nucl Med Radiat Ther 2: 109.

50. Yuan Y, Zhang YS, Qu XJ (2011) The Molecular Alterations Regarding 
Citation: Siddiqui A, Jeevani T, Naga Anusha P, Hima Bindu A (2011) Stem Cell Therapy for Liver Diseases. J Stem Cell Res Ther 1:111. doi:10.4172/2157-7633.1000111

Apoptosis in Hepatocellular Carcinoma Cells at a Glance. J Carcinogene Mutagene 2: 118

51. Sudhakar A (2009) History of Cancer, Ancient and Modern Treatment Methods J Cancer Sci Ther 1: i-iv.

52. Rosarin FS, Mirunalini S (2011) Nobel Metallic Nanoparticles with Nove Biomedical Properties. J Bioanal Biomed 3: 085-091.

53. Sangro B, Iñarrairaegui M (2011) Radioembolization for Hepatocellular Carcinoma: Evidence-Based Answers to Frequently Asked Questions.J Nucl Med Radiat Ther 2:110.

54. Lowe K, Jeyarajah DR (2011) Integration of Surgery and Radioembolization in Treatment of Hepatic Tumors. J NucIMed Radiat Ther 2: 105.

55. Basciano CA, Kleinstreuer C, Kennedy AS (2011) Computational Fluid Dynamics Modeling of 90Y Microspheres in Human Hepatic Tumors. J Nuc Med Radiat Ther 2: 112

56. Gayed IW, Wahba H, Wan D, Joseph U, Murthy R (2010) Effect of Y-90 SIRSpheres Therapy for Multiple Liver Metastases in a Variety of Tumors. J Cancer Sci Ther 2: 043-046.

57. Kennedy A, Dezarn W, Weiss A (2011) Patient Specific 3D Image-Based Radiation Dose Estimates for 90Y Microsphere Hepatic Radioembolization in Metastatic Tumors. J Nucl Med Radiat Ther 2: 111

58. Stutchfield BM, Forbes SJ, Wigmore SJ (2010) Prospects for stem cell transplantation in the treatment of hepatic disease. Liver Transpl 16: 827-836.

59. Ratajczak MZ, Kim CH (2011) Bioactive Sphingolipids and Complement Cascade as New Emerging Regulators of Stem Cell Mobilization and Homing. J Stem Cell Res Ther 1: e102.

60. Khan DR (2010) The Use of Nanocarriers for Drug Delivery in Cancer Therapy. J Cancer Sci Ther 2: 058-062.

61. Anthony L (2011) Neuroendocrine Hepatic Tumors: Summary of Patient Selection, Response and Toxicity of Radioembolization in 281 Patients. J Nucl Med Radiat Ther 2: 104.

62. Vouche M, Vanderlinden B, Delatte P, Lemort M, Hendlisz A, et al. (2011) New Imaging Techniques for $90 \mathrm{Y}$ Microsphere Radioembolization. J Nucl Med Radiat Ther 2: 113.

63. Novik AA, Kuznetsov AN, Melnichenko VY, Fedorenko DA, Ionova TI, et al. (2011) Non-myeloablative Autologous Haematopoietic Stem Cell Transplantation with Consolidation Therapy using Mitoxantrone as a Treatment Option in Multiple Sclerosis Patients. J Stem Cell Res Ther 1: 102.

64. Yu L, Ma J, Ma R, Zhang Y, Zhang X, et al. (2011) Repair of Excitotoxic Neuronal Damage Mediated by Neural Stem Cell Lysates in Adult Mice. J Cell Sci Ther 2: 109.

65. Rosen JE, Yoffe S, Meerasa A, Verma M, Gu FX (2011) Nanotechnology and Diagnostic Imaging: New Advances in Contrast Agent Technology. J Nanomedic Nanotechnol 2: 115.

66. Dronca RS, Markovic SN, Holtan SG, Porrata LF (2011) Neuro-endocrineimmune Crosstalk and Implications for Cancer Therapy. J Cell Sci Ther 2: 102e.

67. Vinken M (2011) Mathieu Vinken's Work on the Role of Connexin-related Signalling in Hepatic Homeostasis and its Relevance for Liver based In vitro Modelling. Pharm Anal Acta 2: 101e.

68. Porrata LF, Inwards DJ, Ansell SM, Micallef IN, Johnston PB, et al. (2011) Day 15 Peripheral Blood Lymphocyte/monocyte Ratio Postautologous Periphera Hematopoietic Stem Cell Transplantation and Survival in Diffuse Large B-cell Lymphoma. J Stem Cell Res Ther 1: 103.

69. Hwang J, Lee S, Park H, Kim M (2010) Autologous Bone Marrow Transplantation in Osteonecrosis of the Femoral Head. J Tissue Sci Eng 2: 103.

70. Nikeghbalian S, Pournasr B, Aghdami N, Rasekhi A, Geramizadeh B, et al. (2011) Autologous transplantation of bone marrow-derived mononuclear and CD133 (+) cells in patients with decompensated cirrhosis. Arch Iran Med 14 $12-17$.

71. Ghodsizad A, Voelkel T, Moebius JM, Gregoric I, Bordel V, et al. (2010) Biological Similarities Between Mesenchymal Stem Cells (Mscs) and Fibroblasts. J Cytol Histol 1: 101.

72. Gilchrist ES, Plevris JN (2010) Bone marrow-derived stem cells in liver repair: 10 years down the line. Liver Transpl 16: 118-29.
73. Basma H Soto-Gutiérrez A, Yannam GR, Liu L, Ito R, et al. (2009) Differentiation and transplantation of human embryonic stem cell-derived hepatocytes. Gastroenterology 136: 990-999.

74. Liu DM, Cade D, Klass D, Loh C, McWilliams JP, et al. (2011) Interventional Oncology - Avoiding Common Pitfalls to ReduceToxicity in Hepatic Radioembolization. J Nucl Med Radiat Ther 2: 106.

75. Rameshwar P (2011) Post-identification of Cancer Stem Cell: Ethical and Scientific Dilemmas in Therapeutic Development?. J Stem Cell Res Ther 1 e101.

76. Chiang $\mathrm{CH}$, Chang $\mathrm{CC}$, Huang HC, Chen YJ, Tsai PH, et al. (2011) Investigation of hepatoprotective activity of induced pluripotent stem cells in the mouse model of liver injury. J Biomed Biotechnol 219060

77. Si-Tayeb K, Noto FK, Nagaoka M, Li J, Battle MA, et al. (2010) Highly efficien generation of human hepatocyte-like cells from induced pluripotent stem cells. Hepatology 51: 297-305

78. Zhou P, Hohm S, Olusanya Y, Hess DA, Nolta J (2009) Human progenitor cells with high aldehyde dehydrogenase activity efficiently engraft into damaged liver in a novel model. Hepatology 49: 1992-2000.

79. Zhang FT, Wan HJ, Li MH, Ye J, Yin MJ, (2011) Transplantation of microencapsulated umbilical-cord-blood-derived hepatic-like cells for treatment of hepatic failure. World J Gastroenterol 17: 938-945.

80. Brezillon N, Kremsdorf D, Weiss MC (2008) Cell therapy for the diseased liver: from stem cell biology to novel models for hepatotropic human pathogens. Dis Model Mech 1: 113-30

81. Minguell JJ, Pereira A, Bartholomew P, Lasala GP (2011) The Intrathecal Infusion of Mesenchymal Stem Cells into Healthy Rabbits is Safe and Devoid of Neurological or Clinical Complications. J Stem Cell Res Ther 1: 104.

82. Ponnusamy MP (2010) Stem Cell Research and Cancer Stem Cells. J Tissue Sci Eng 2:104e.

83. Zhou P, Wirthlin L, McGee J, Annett G, Nolta J (2009) Contribution of human hematopoietic stem cells to liver repair. Semin Immunopathol 31: 411-419.

84. Roelandt $P$, Pauwelyn KA, Sancho-Bru P, Subramanian K, Ordovas L, et al. (2010) Human embryonic and rat adult stem cells with primitive endodermlike phenotype can be fated to definitive endoderm, and finally hepatocytelike cells. PLoS One 5: e12101.

85. Li H, Lu Y, Witek RP, Chang LJ, Campbell-Thompson M, et al. (2010) Ex vivo transduction and transplantation of bone marrow cells for liver gene delivery of alpha1-antitrypsin. Mol Ther 18: 1553-1558. 